\title{
MATRIK
}

Jurnal Manajemen dan Teknik Industri-Produksi

Journal homepage: http://www.journal.umg.ac.id/index.php/matriks

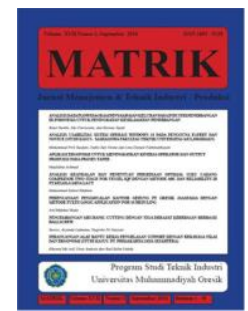

\section{Usulan Preventive Maintenance Pada Mesin Hanger Shot Blast Kazo Dengan Menggunakan Metode Age Replacement Di PT Barata Indonesia}

\author{
Edo Ardo Agustiawan ${ }^{1 *}$, Muhammad Zainuddin Fathoni ${ }^{2}$, Dzakiyah Widyaningrum ${ }^{3}$ \\ Program Studi Teknik Industri, Fakultas Teknik, Universitas Muhammadiyah Gresik \\ Jl. Sumatera No. 101 GKB, Gresik (61121), Jawa Timur, Indonesia \\ edwardagustiawan@gmail.com ${ }^{1 *}$, zainuddin@umg.ac.id ${ }^{2}$, dzakiyah@umg.ac.id ${ }^{3}$
}

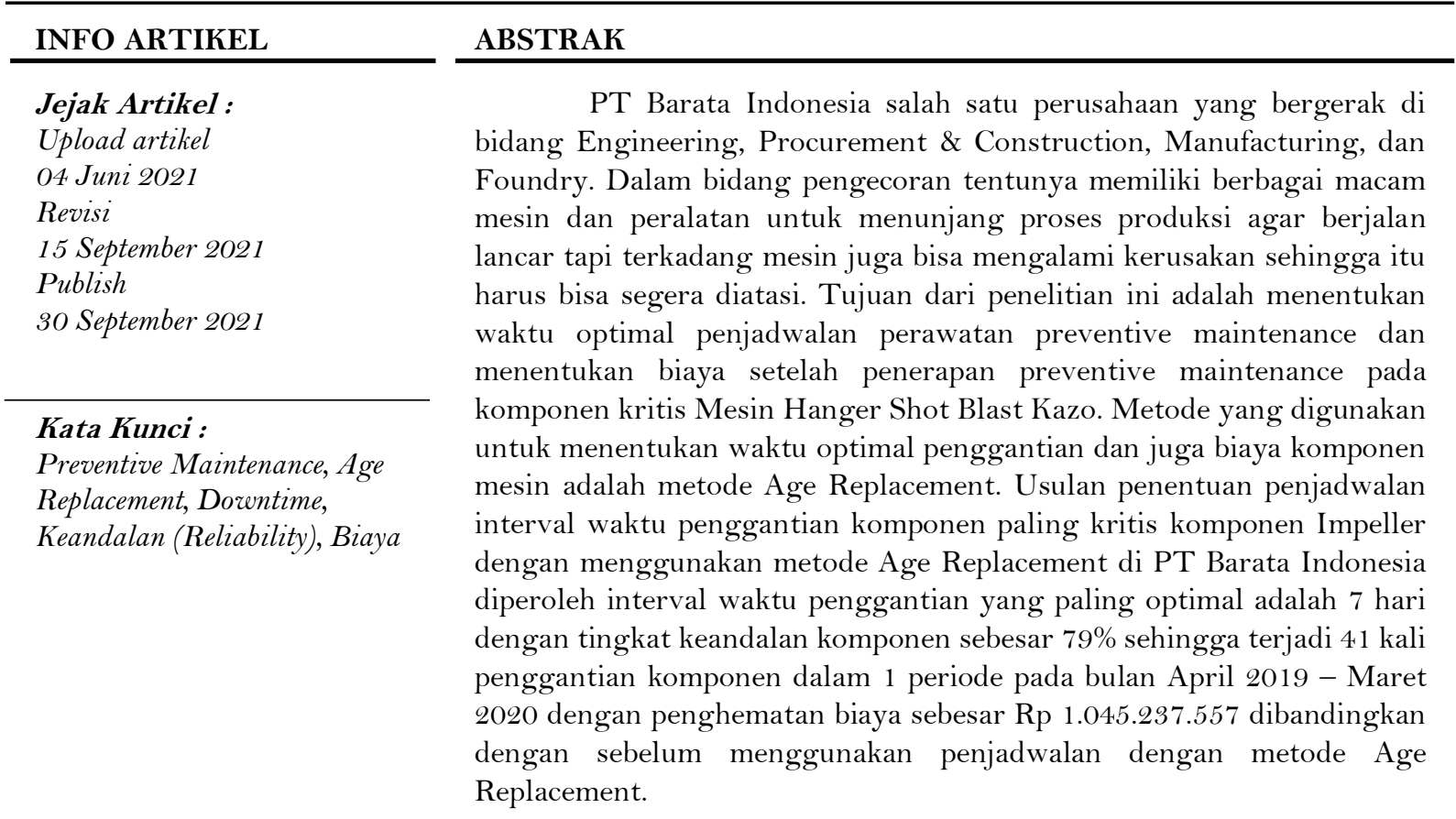




\section{Pendahuluan}

Di era industri yang semuanya serba canggih tentunya tidak lepas dengan mesin atau alat yang berfungsi untuk membantu keandalan mesin-mesin dalam produksi yang mempunyai kinerja yang baik guna menunjang proses produksi dan meningkatkan hasil dari produksi agar perusahaan memperoleh keuntungan yang maksimal[1][2]. Tapi pada kenyataannya, keandalan pada mesin akan mengalami penurunan kinerja mesin dikarenakan pemakaian yang terus menerus dan termakan oleh usia, maka dari itu perawatan harus dilakukan untuk menjaga produktifitas sebuah mesin baik perawatan secara preventif ataupun korektif. Kegiatan perawatan (maintenance) ditujukan untuk meraih tingkat biaya perawatan serendah mungkin, dengan melakukan kegiatan maintenance secara efektif dan efisien keseluruhannya[3][4].

Maintenance mempunyai peranan yang penting dalam keandalan (reliability) dan pemeliharaan peralatan maupun mesin mesin produksi agar suatu proses produksi bisa berjalan dengan lancar. keandalan merupakan peluang suatu unit atau sistem berfungsi normal jika digunakan menurut kondisi operasi tertentu untuk periode waktu tertentu[5][6][7].

PT. Barata Indonesia merupakan perusahaan yang bergerak di berbagai bidang seperti Engineering, Procurement \& Construction, Manufacturing, dan Foundry. PT Barata Indonesia mempunyai 4 Workshop, dan salah satunya adalah WS 1 dan 2 yang bergerak di bidang pengecoran. WS 1 berupa proses produksi dan finishing, sedangkan di WS 2 berisi Machining.

Pada periode April 2019 - Maret 2020 telah terjadi kerusakan mesin sebanyak 400 kali di bagian proses yaitu WS 1, bisa dilihat di tabel 1.1 dan itu mengakibatkan proses produksi terganggu. Data downtime mesin produksi periode bulan April 2019 - Maret 2020 dapat dilihat pada tabel 1.

Tabel 1. Downtime Mesin produksi WS I

\begin{tabular}{|c|c|c|c|c|}
\hline No & $\begin{array}{c}\text { Nama } \\
\text { Mesin / } \\
\text { Alat }\end{array}$ & Frekuensi & $\begin{array}{c}\text { Downtime } \\
\text { (jam) }\end{array}$ & $\begin{array}{c}\text { Persentase } \\
\text { Downtime }\end{array}$ \\
\hline 1 & $\begin{array}{c}\text { Cetak UG F } \\
1-3\end{array}$ & 11 & 21 & $2 \%$ \\
\hline 2 & $\begin{array}{c}\text { Cetak UG F } \\
2-4\end{array}$ & 13 & 35 & $3 \%$ \\
\hline 3 & $\begin{array}{c}\text { Sand } \\
\text { Preparation }\end{array}$ & 10 & 33 & $2 \%$ \\
\hline 4 & $\begin{array}{c}\text { Continues } \\
\text { Mixer EF }\end{array}$ & 1 & 2 & $0 \%$ \\
\hline
\end{tabular}

\begin{tabular}{|c|c|c|c|c|}
\hline 5 & $\begin{array}{c}\text { Shake Out } \\
\text { HM EF }\end{array}$ & 20 & 56 & $4 \%$ \\
\hline 6 & $\begin{array}{c}\text { Mixer Core } \\
\text { CD }\end{array}$ & 27 & 55 & $4 \%$ \\
\hline 7 & $\begin{array}{c}\text { Rollover } \\
\text { Stripping }\end{array}$ & 22 & 54 & $4 \%$ \\
\hline 8 & $\begin{array}{c}\text { Continues } \\
\text { Mixer Core }\end{array}$ & 12 & 25 & $2 \%$ \\
\hline 9 & $\begin{array}{c}\text { Sand } \\
\text { Reclamation }\end{array}$ & 77 & 237 & $18 \%$ \\
\hline 10 & $\begin{array}{c}\text { Sand Mixer } \\
\text { Core }\end{array}$ & 3 & 4 & $1 \%$ \\
\hline 11 & $\begin{array}{c}\text { Hanger SB } \\
\text { Kazo }\end{array}$ & $\mathbf{8 5}$ & $\mathbf{2 8 6 , 5}$ & $\mathbf{2 1 \%}$ \\
\hline 12 & $\begin{array}{c}\text { Hanger SB } \\
\text { By AB Sinto }\end{array}$ & 50 & 174 & $13 \%$ \\
\hline 13 & $\begin{array}{c}\text { Table Shot } \\
\text { Blast }\end{array}$ & 18 & 62,5 & $5 \%$ \\
\hline 14 & HT 6 Ton & 16 & 44 & $3 \%$ \\
\hline 15 & HT 16 Ton & 17 & 47 & $3 \%$ \\
\hline 16 & AF 5 Ton & 6 & 177 & $13 \%$ \\
\hline 17 & AF 10 Ton & 0 & 0 & $0 \%$ \\
\hline 18 & Ind 2 ton & 1 & 4 & $0 \%$ \\
\hline 19 & $\begin{array}{c}\text { Hanger } \\
\text { Putih / Bitek }\end{array}$ & 12 & 32 & $2 \%$ \\
\hline & Total & 401 & 1349 & $100 \%$ \\
\hline
\end{tabular}

Berdasarkan hasil identifikasi yang telah diuraikan di atas, perawatan komponen kritis pada mesin Hanger Shot Blast Kazo mempunyai tujuan untuk meminimalisir terjadinya kerusakan pada mesin Hanger Shot Blast Kazo. Metode yang digunakan pada penelitian ini adalah preventive maintenance dengan pendekatan Age Replacement [8][9][10].

Dengan menggunakan metode Age Replacement diharapkan mampu membantu memperoleh interval waktu penggantian komponen mesin Hanger Shot Blast Kazo dan mengetahui penurunan downtime serta penghematan dari biaya yang dikeluarkan[11][12][13][14]. Dalam penelitian ini juga memberikan masukan kepada perusahaan untuk menentukan kebijakan lebih lanjut dalam penggantian komponen yang kritis pada mesin Hanger Shot Blast Kazo dan dapat dijadikan bahan pertimbangan dalam pengambilan keputusan serta menimimalkan biaya penggantian yang dibebankan perusahaan[15].

\section{Metode Penelitian}

Pada bab ini diuraikan secara sistematis mengenai Langkah-langkah yang dilakukan dalam penelitian yang ditampilkan pada gambar 1 . 


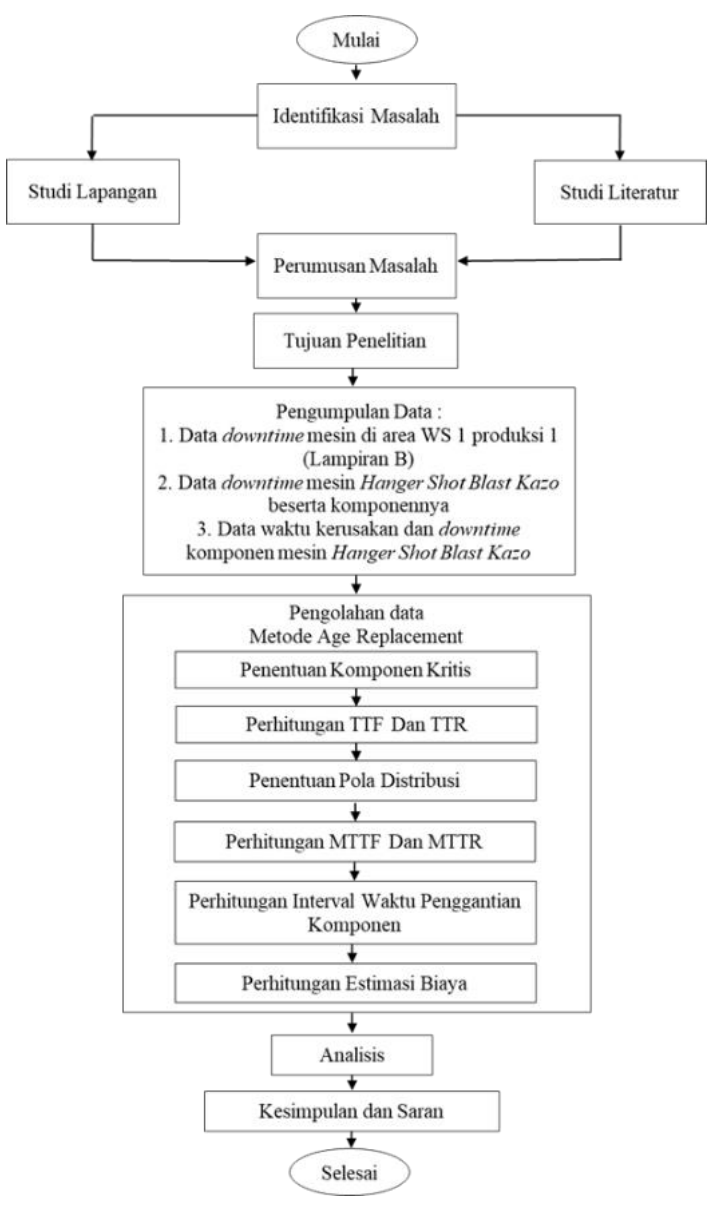

Gambar 1. Flowchart Penelitian

\section{Identifikasi Masalah}

Tahapan dimana mencari adanya permasalahan yang ada di produksi 1 yang berhubungan dengan bagian maintenance di PT Barata Indonesia khususnya area WS 1 Produksi 1.

\section{Studi Lapangan Dan Literatur}

Tahapan yang dilakukan dengan cara observasi langsung di area lapangan dengan cara wawancara kepada karyawan bagian maintenance dan juga mencari informasiinformasi yang berupa buku, referensi, katalog, jurnal penelitian, dan sumber literatur lain yang akan menunjang langkah-langkah dalam penelitian ini adalah preventive maintenance dengan menggunakan metode Age Replacement.

\section{Perumusan Masalah}

Untuk menentukan permasalahan yang terjadi pada PT Barata Indonesia perlu dilakukan identifikasi masalah yang ada di area bersangkutan yaitu area WS 1 .

\section{Tujuan Penelitian}

Untuk menganalisa dan mengevaluasi kerusakan yang terjadi dan membuat interval perawatan yang optimal.

\section{Pengumpulan Data}

Data yang dibutuhkan dalam penelitian ini meliputi data downtime mesin di area WS 1, data downtime mesin Hanger Shot Blast Kazo beserta komponennya dan data waktu kerusakan dan lama perbaikan komponen Hanger Shot Blast Kazo

\section{Pengolahan Data}

Tahapan yang dilakukan dalam pengolahan data setelah mengetahui data dari frekuensi kerusakan mesin dan downtime pada mesin Hanger Shot Blast Kazo adalah menentukan komponen kritis, perhitungan TTF dan TTR, menentukan pola distribusi dari TTF dan TTR, perhitungan estimasi parameter, perhitungan MTTF dan MTTR, perhitungan reliability, perhitungan interval waktu penggantian komponen, dan yang terakhir adalah perhitungan estimasi biaya.

Lalu tahapan berikutnya adalah menganalisa hasil perhitungan MTTF, MTTR, nilai reliability mesin, interval waktu perawatan mesin dan estimasi biaya perawatan mesin apabila menggunakan metode Age Replacement. Setelah analisa yang dilakukan maka dapat memperoleh kesimpulan dari penelitian ini dan juga dapat diajukan beberapa usulan yang nantinya mendapatkan perawatan yang efektif dan efisien bagi perusahaan PT Barata Indonesia khususnya pada mesin Hanger Shot Blast Kazo.

\section{Hasil dan Pembahasan}

Berdasarkan tabel 1, data downtime mesin yang dikumpulkan pada bulan April 2019 Maret 2020, mesin Hanger Shot Blast Kazo mengalami frekuensi kerusakan paling banyak di area WS 1.

\section{Penentuan Komponen Kritis}

Untuk menentukan komponen yang paling kritis pada mesin Hanger Shot Blast dapat dilakukan dengan cara pembuatan grafik histogram pada gambar 2, untuk memudahkan komponen yang memiliki banyak maupun sedikit frekuensi kerusakan. 


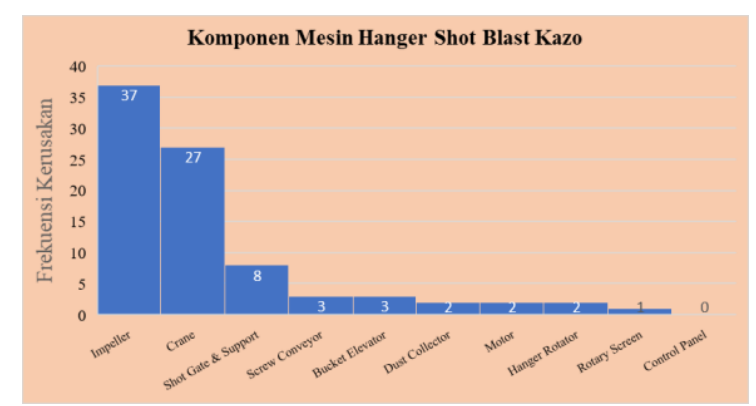

Gambar 2. Grafik histogram komponen mesin Hanger Shot Blast Kazo

Dari gambar 2 diatas dapat diketahui bahwa komponen kritis pada mesin Hanger Shot Blast Kazo adalah komponen Impeller dengan frekuensi kerusakan paling banyak yaitu 37 kerusakan.

\section{Data Waktu Antar Kerusakan (TTF) Dan Lama Perbaikan (TTR)}

TTF adalah waktu antar kerusakan yang dihitung berdasarkan waktu saat komponen mesin telah diperbaiki hingga waktu mesin diperbaiki selanjutnya. TTR adalah waktu yang diperlukan agar mesin tersebut dapat dioperasikan dalam keadaan normal. Hasil perhitungan nilai TTF dan TTR dapat dilihat pada tabel 2 dan 3.

Tabel 2. TTF komponen impeller

\begin{tabular}{|c|c|c|}
\hline No & $\begin{array}{c}\text { Tanggal Terjadinya } \\
\text { Kerusakan }\end{array}$ & $\begin{array}{c}\text { Jarak Antar Kerusakan } \\
\text { (Hari) }\end{array}$ \\
\hline 1 & $05 / 04 / 2019$ & 0 \\
\hline 2 & $11 / 04 / 2019$ & 6 \\
\hline 3 & $18 / 04 / 2019$ & 7 \\
\hline 4 & $26 / 04 / 2019$ & 8 \\
\hline 5 & $03 / 05 / 2019$ & 7 \\
\hline 6 & $13 / 05 / 2019$ & 10 \\
\hline 7 & $21 / 05 / 2019$ & 8 \\
\hline 8 & $01 / 06 / 2019$ & 10 \\
\hline 9 & $10 / 06 / 2019$ & 9 \\
\hline 10 & $14 / 06 / 2019$ & 4 \\
\hline 11 & 19/06/2019 & 5 \\
\hline 12 & $04 / 07 / 2019$ & 15 \\
\hline 13 & $18 / 07 / 2019$ & 14 \\
\hline 14 & $30 / 07 / 2019$ & 12 \\
\hline 15 & 09/08/2019 & 9 \\
\hline 16 & $16 / 08 / 2019$ & 7 \\
\hline 17 & 23/08/2019 & 7 \\
\hline 18 & $03 / 09 / 2019$ & 10 \\
\hline 19 & 09/09/2019 & 6 \\
\hline 20 & $19 / 09 / 2019$ & 10 \\
\hline
\end{tabular}

\begin{tabular}{|l|l|c|}
\hline 21 & $28 / 09 / 2019$ & 9 \\
\hline 22 & $08 / 10 / 2019$ & 10 \\
\hline 23 & $16 / 10 / 2019$ & 8 \\
\hline 24 & $24 / 10 / 2019$ & 8 \\
\hline 25 & $07 / 11 / 2019$ & 13 \\
\hline 26 & $20 / 11 / 2019$ & 5 \\
\hline 27 & $25 / 11 / 2019$ & 12 \\
\hline 28 & $07 / 12 / 2019$ & 11 \\
\hline 29 & $18 / 12 / 2019$ & 12 \\
\hline 30 & $30 / 12 / 2019$ & 11 \\
\hline 31 & $11 / 01 / 2020$ & 12 \\
\hline 32 & $23 / 01 / 2020$ & 8 \\
\hline 33 & $01 / 02 / 2020$ & 9 \\
\hline 34 & $10 / 02 / 2020$ & 7 \\
\hline 35 & $17 / 02 / 2020$ & 8 \\
\hline 36 & $25 / 02 / 2020$ & 11 \\
\hline 37 & $06 / 03 / 2020$ & \\
\hline
\end{tabular}

Tabel 3. TTR komponen Impeller

\begin{tabular}{|c|c|c|c|}
\hline No & Tanggal Mulai & $\begin{array}{c}\text { Tanggal } \\
\text { Selesai }\end{array}$ & $\begin{array}{c}\text { Lama } \\
\text { Perbaikan } \\
\text { (Jam) }\end{array}$ \\
\hline 1 & $05 / 04 / 2019$ & $05 / 04 / 2019$ & 5 \\
\hline 2 & $11 / 04 / 2019$ & $11 / 04 / 2019$ & 6 \\
\hline 3 & $18 / 04 / 2019$ & $18 / 04 / 2019$ & 3 \\
\hline 4 & $26 / 04 / 2019$ & $26 / 04 / 2019$ & 4 \\
\hline 5 & $03 / 05 / 2019$ & $03 / 05 / 2019$ & 3 \\
\hline 6 & $13 / 05 / 2019$ & $13 / 05 / 2019$ & 4 \\
\hline 7 & $21 / 05 / 2019$ & $21 / 05 / 2019$ & 4 \\
\hline 8 & $01 / 06 / 2019$ & $01 / 06 / 2019$ & 3 \\
\hline 9 & $10 / 06 / 2019$ & $10 / 06 / 2019$ & 4 \\
\hline 10 & $14 / 06 / 2019$ & $14 / 06 / 2019$ & 4 \\
\hline 11 & $19 / 06 / 2019$ & $19 / 06 / 2019$ & 4 \\
\hline 12 & $04 / 07 / 2019$ & $04 / 07 / 2019$ & 4 \\
\hline 13 & $18 / 07 / 2019$ & $18 / 07 / 2019$ & 4 \\
\hline 14 & $30 / 07 / 2019$ & $30 / 07 / 2019$ & 5 \\
\hline 15 & $09 / 08 / 2019$ & $09 / 08 / 2019$ & 2,5 \\
\hline 16 & $16 / 08 / 2019$ & $16 / 08 / 2019$ & 2 \\
\hline 17 & $23 / 08 / 2019$ & $23 / 08 / 2019$ & 2 \\
\hline 18 & $03 / 09 / 2019$ & $03 / 09 / 2019$ & 4 \\
\hline 19 & $09 / 09 / 2019$ & $09 / 09 / 2019$ & 4 \\
\hline 20 & $19 / 09 / 2019$ & $19 / 09 / 2019$ & 3 \\
\hline 21 & $28 / 09 / 2019$ & $28 / 09 / 2019$ & 4 \\
\hline 22 & $08 / 10 / 2019$ & $08 / 10 / 2019$ & 6 \\
\hline 23 & $16 / 10 / 2019$ & $16 / 10 / 2019$ & 6 \\
\hline 24 & $24 / 10 / 2019$ & $24 / 10 / 2019$ & 5 \\
\hline 25 & $07 / 11 / 2019$ & $07 / 11 / 2019$ & 4 \\
\hline 26 & $20 / 11 / 2019$ & $20 / 11 / 2019$ & 2 \\
\hline
\end{tabular}




\begin{tabular}{|c|c|c|c|}
\hline 27 & $25 / 11 / 2019$ & $25 / 11 / 2019$ & 2 \\
\hline 28 & $07 / 12 / 2019$ & $07 / 12 / 2019$ & 2 \\
\hline 29 & $18 / 12 / 2019$ & $18 / 12 / 2019$ & 1,5 \\
\hline 30 & $30 / 12 / 2019$ & $30 / 12 / 2019$ & 3 \\
\hline 31 & $11 / 01 / 2020$ & $11 / 01 / 2020$ & 4 \\
\hline 32 & $23 / 01 / 2020$ & $23 / 01 / 2020$ & 3 \\
\hline 33 & $01 / 02 / 2020$ & $01 / 02 / 2020$ & 4 \\
\hline 34 & $10 / 02 / 2020$ & $10 / 02 / 2020$ & 3 \\
\hline 35 & $17 / 02 / 2020$ & $17 / 02 / 2020$ & 1,5 \\
\hline 36 & $25 / 02 / 2020$ & $25 / 02 / 2020$ & 2 \\
\hline 37 & $06 / 03 / 2020$ & $06 / 03 / 2020$ & 4 \\
\hline
\end{tabular}

\section{Penentuan Pola Distribusi Waktu Antar Kerusakan (TTF)}

Penentuan pola distribusi bisa didapatkan dengan memasukkan data waktu antar kerusakan pada tabel 2. Dari tabel tersebut kemudian akan dilakukan pengujian menentukan distribusi dengan bantuan software Minitab 18 dan kemudian hasil yang didapatkan adalah seperti gambar di bawah ini.

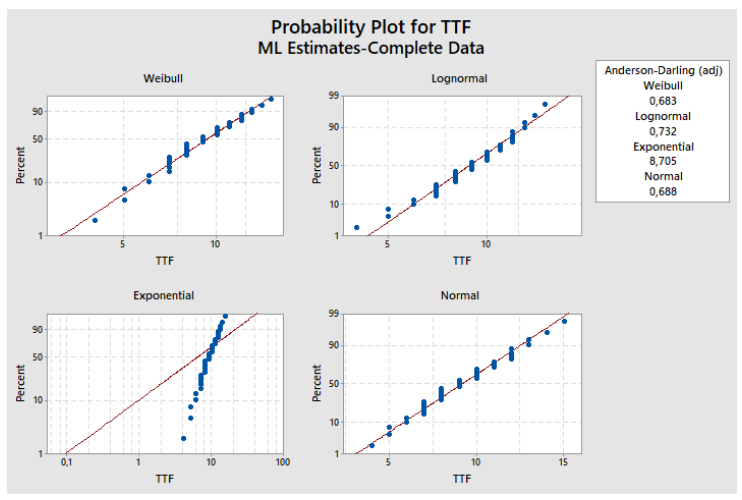

Gambar 3. Penentuan distribusi TTF komponen impeller

Berdasarkan gambar 3 diatas, suatu data dikatakan mengikuti distribusi tertentu apabila nilai statistik Anderson-Darling semakin kecil. Nilai yang dimaksud adalah square error. Diantara 4 distribusi yang telah diuji, distribusi yang bernilai statistik Anderson-Darling paling kecil adalah distribusi weibul dengan nilai 0,663 . Jadi, data waktu antar kerusakan komponen impeller pada mesin Hanger Shot Blast Kazo adalah distribusi weibull.

\section{Penentuan Pola Distribusi Lama Perbaikan (TTR)}

Sedangkan untuk penentuan pola distribusi lama perbaikan (TTR) bisa didapatkan seperti gambar dibawah ini.

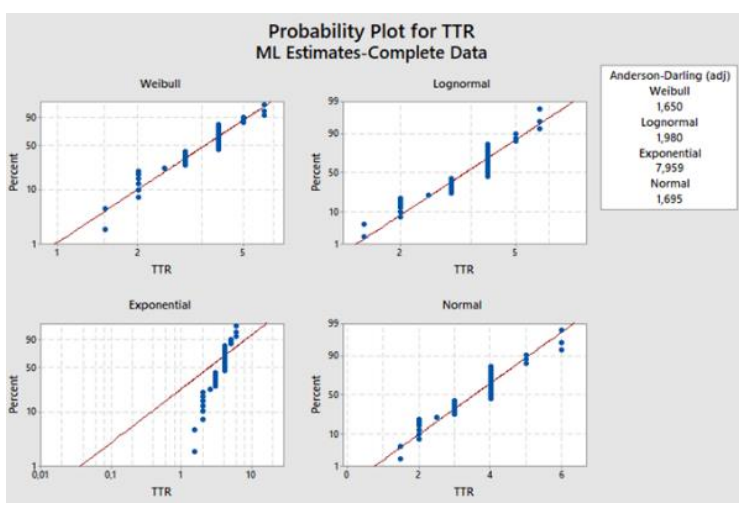

Gambar 4. Penentuan distribusi TTR komponen impeller

Berdasarkan gambar 4 diatas, diantara 4 distribusi yang telah diuji, distribusi yang bernilai statistik Anderson-Darling paling kecil adalah distribusi weibul dengan nilai 1,650. Jadi, data waktu lama perbaikan (downtime) komponen impeller pada mesin Hanger Shot Blast Kazo adalah distribusi weibull.

\section{Perhitungan Estimasi Parameter}

Perhitungan parameter digunakan untuk mengetahui nilai $\beta$ (shape parameter) dan $\theta$ (scale parameter) setelah distribusi telah ditentukan.Untuk menentukan distribusi adalah dengan cara menghitung jarak antar kerusakan pada komponen, kemudian memasukkan data jarak antar kerusakan ke dalam aplikasi Minitab 18. Perhitungan parameter yang digunakan pada komponen kritis impeller ini adalah distribusi weibull.

\section{Perhitungan Estimasi Parameter TTF Komponen Impeller}

Berikut merupakan perhitungan mencari nilai $\beta$ (shape parameter) dan $\theta$ (scale parameter) TTF yang dapat dilihat pada tabel 5 dibawah ini.

Tabel 4. TTF komponen impeller

\begin{tabular}{|c|c|c|c|c|c|c|c|}
\hline No & $\mathrm{ti}$ & $\begin{array}{c}Y i=\ln \\
t i\end{array}$ & $\mathrm{Yi}^{\wedge}{ }^{2}$ & $\mathrm{~F}(\mathrm{ti})$ & $\begin{array}{l}\mathrm{Xi}= \\
\mathrm{In} \ln \end{array}$ & $\mathrm{Xi}^{\wedge} 2$ & $\mathrm{XiYi}$ \\
\hline 1 & 4 & $\begin{array}{c}1,38629 \\
4\end{array}$ & 1,921812 & $\begin{array}{c}0,01923 \\
1\end{array}$ & $\begin{array}{c}3,94155 \\
0\end{array}$ & $\begin{array}{c}15,5358 \\
19\end{array}$ & $\begin{array}{c}5,46414 \\
9\end{array}$ \\
\hline 2 & 5 & $\begin{array}{c}1,60943 \\
8\end{array}$ & 2,590290 & $\begin{array}{c}0,04670 \\
3\end{array}$ & $\begin{array}{c}3,04012 \\
1\end{array}$ & $\begin{array}{c}9,24233 \\
7\end{array}$ & $\begin{array}{c}4,89288 \\
6\end{array}$ \\
\hline 36 & 15 & $\begin{array}{c}2,70805 \\
0\end{array}$ & 7,333536 & $\begin{array}{c}0,98076 \\
9\end{array}$ & $\begin{array}{c}1,37403 \\
0\end{array}$ & $\begin{array}{c}1,88796 \\
0\end{array}$ & $\begin{array}{c}3,72094 \\
3\end{array}$ \\
\hline $\begin{array}{c}\text { Juml } \\
\text { ah }\end{array}$ & $\begin{array}{c}33 \\
1\end{array}$ & $\begin{array}{c}78,3070 \\
32\end{array}$ & $\begin{array}{c}173,6260 \\
04\end{array}$ & $\begin{array}{c}18,0000 \\
00\end{array}$ & $\begin{array}{c}- \\
20,0250 \\
17\end{array}$ & $\begin{array}{c}62,0751 \\
69\end{array}$ & $\begin{array}{c}- \\
30,7358 \\
44\end{array}$ \\
\hline
\end{tabular}

Rumus dari tabel perhitungan diatas adalah sebagai berikut : 

a. $\mathrm{Yi}=\ln t i$
$=\ln (4)$
$=1,386294$
b. $Y i^{2}=(1,386294)^{2}$
$=1,921812$
c. $\mathrm{F}(\mathrm{ti})=\frac{(i-0,3)}{(n+0,4)}$
$=\frac{(1-0,3)}{(36+0,4)}$
$=0,019231$
d. $\mathrm{Xi}=\ln \ln \left[\frac{1}{(1-F(t i))}\right]$
$=\ln \ln \left[\frac{1}{(1-0,019231)}\right]$
$=-3,94155$
e. $X i^{2}=(-3,94155)^{2}$
$=15,535819$
f. $X i Y i=1,386294 *(-3,94155)$
$=-5,464149$

g. $\quad \beta$ (shape parameter)

$$
\begin{aligned}
b & =\frac{n \sum_{i=1}^{n} X i Y i-\left(\sum_{i=1}^{n} X i\right)\left(\sum_{i=1}^{n} Y i\right)}{n \sum_{i=1}^{n} X i^{2}-\left(\sum_{i=1}^{n} X i\right)^{2}} \\
& =\frac{(36 *(-30,735844))-(-20,025) *(78,307032)}{(36 * 62,075)-(-20,025)^{2}} \\
& =0,25173 \\
\beta & =\frac{1}{b} \\
& =\frac{1}{0,25173} \\
& =3,97241 \\
a & =\frac{\sum Y i-b * \sum X i}{n} \\
a & =\frac{(78,307032)-(0,25173) *(-20,025)}{36} \\
& =2,31522
\end{aligned}
$$

h. $\theta$ (scale parameter)

$$
\begin{array}{ll}
\theta & =e^{-a}=\exp (a) \\
\theta & =2,718(2,31522) \\
& =10,12718
\end{array}
$$

\section{Perhitungan Estimasi Parameter TTR Komponen Impeller}

Berikut merupakan perhitungan mencari nilai $\beta$ (shape parameter) dan $\theta$ (scale parameter) TTR yang dapat dilihat pada tabel 4.6 dibawah ini.

Tabel 5. TTR komponen impeller

\begin{tabular}{|c|c|c|c|c|c|c|c|}
\hline $\mathrm{tp}$ & $\mathrm{ti}$ & $\mathrm{yi}$ & $\mathrm{yi2}$ & $\mathrm{f}(\mathrm{ti})$ & $\mathrm{xi}$ & $\mathrm{xi2}$ & $\mathrm{xiyi}$ \\
\hline 1 & 1,5 & 0,40547 & 0,16440 & $\begin{array}{c}0,0187 \\
2\end{array}$ & $\begin{array}{c}- \\
3,96891\end{array}$ & $\begin{array}{c}15,7522 \\
7\end{array}$ & $\begin{array}{c}- \\
1,6092 \\
6\end{array}$ \\
\hline 2 & 1,5 & 0,40547 & 0,16440 & $\begin{array}{c}0,0454 \\
5\end{array}$ & $\begin{array}{c}3,06787 \\
-\end{array}$ & 9,41184 & $\begin{array}{c}1,2439 \\
2\end{array}$ \\
\hline 37 & 6 & 1,79176 & 3,21040 & 0,9812 & 1,38087 & 1,90679 & $\begin{array}{c}2,4741 \\
8\end{array}$ \\
\hline jumla & 131, & 44,5744 & 58,7290 & 18,5 & - & 63,9755 & - \\
$\mathrm{h}$ & 5 & 0 & 1 & & 20,5975 & & $\begin{array}{c}9,1882 \\
7\end{array}$ \\
\hline
\end{tabular}

Rumus dari tabel perhitungan diatas adalah sebagai berikut :

$$
\begin{aligned}
\text { a. } \quad \mathrm{Yi} & =\ln t i \\
& =\ln (1,5) \\
& =0,40547 \\
\text { b. } \quad i^{2} \quad & =(0,40547)^{2} \\
& =0,16440 \\
\text { c. } \quad \mathrm{F}(\mathrm{ti}) \quad & =\frac{(i-0,3)}{(n+0,4)} \\
& =\frac{(1-0,3)}{(37+0,4)} \\
& =0,01872 \\
\text { d. } \quad \mathrm{Xi} \quad & \ln \ln \left[\frac{1}{(1-F(t i))}\right] \\
& =\ln \ln \left[\frac{1}{(1-0,01872)}\right] \\
\text { e. } \quad X i^{2} \quad & =(-3,96891 \\
\text { f. } \quad X i Y i & =1,94155)^{2} \\
& =-1,6092629 *(-3,94155)
\end{aligned}
$$

g. $\quad \beta$ (shape parameter)

$$
\begin{aligned}
b & =\frac{n \sum_{i=1}^{n} X i Y i-\left(\sum_{i=1}^{n} X i\right)\left(\sum_{i=1}^{n} Y i\right)}{n \sum_{i=1}^{n} X i^{2}-\left(\sum_{i=1}^{n} X i\right)^{2}} \\
b & =\frac{(37 *(-9,18827))-(-20,5975) *(44,57440)}{(37 * 63,9755)-(-20,59755)^{2}} \\
& =0,29758 \\
\beta & =\frac{1}{b} \\
& =\frac{1}{0,29758} \\
& =3,36038 \\
a & =\frac{\sum Y i-b * \sum X i}{n} \\
a & =\frac{(44,57440)-(0,29758) *(-20,59755)}{37} \\
& =1,37037
\end{aligned}
$$

h. $\vartheta$ (scale parameter)

$$
\begin{aligned}
\theta & =e^{-a}=\exp (a) \\
\theta & =2,718(1,37037) \\
& =3,72466
\end{aligned}
$$

\section{Perhitungan MTTF dan MTTR}

Berikut ini adalah perhitungan nilai (Mean Time to Failure) MTTF dan (Mean Time to Repair) MTTR untuk distribusi weibull:

a. $\operatorname{MTTF}=\theta \cdot \Gamma\left(1+\frac{1}{\beta}\right)$

$$
\begin{aligned}
& M T T F=10,12718 . \Gamma\left(1+\frac{1}{3,97241}\right) \\
& M T T F=10,12718 . \Gamma(1,25) \\
& M T T F=10,12718(0,90640) \\
& M T T F=9,18 \text { hari atau 220,32 jam }
\end{aligned}
$$


Nilai $\theta . \Gamma\left(1+\frac{1}{\beta}\right)$ dapat dilihat pada tabel dari fungsi Gamma di (Lampiran A), dimana nilai $\Gamma(1,25)$ adalah 0,90640 .

MTTF adalah waktu rata - rata jarak kerusakan komponen atau mesin yang pertama sampai kerusakan berikutnya. Berdasarkan perhitungan diatas pada periode bulan April 2019 - Maret 2020, rata rata waktu kerusakan komponen impeller pada mesin Hanger Shot Blast Kazo adalah sebesar 9,18 hari atau 220,32 jam.

b. $M T T R=\theta . \Gamma\left(1+\frac{1}{\beta}\right)$

$\operatorname{MTTR}=3,72466 . \Gamma\left(1+\frac{1}{3,36038}\right)$

$M T T R=3,72466 . \Gamma(1,29)$

$M T T R=3,72466(0,89904)$

$M T T R=3,34$ jam

Nilai $\theta . \Gamma\left(1+\frac{1}{\beta}\right)$ dapat dilihat pada tabel dari fungsi Gamma di (Lampiran A), dimana nilai $\Gamma(1,25)$ adalah 0,89904.

MTTR adalah waktu rata - rata yang diperlukan pada saat perbaikan komponen ataupun mesin. Berdasarkan perhitungan diatas pada periode bulan April 2019 - Maret 2020, rata rata waktu perbaikan komponen impeller pada mesin Hanger Shot Blast Kazo adalah sebesar 3,34 jam.

\section{Perhitungan Reliability Pada Komponen} Impeller

Nilai keandalan dapat dihitung dengan rumus :

$R(t)=\exp \left[\left(-\frac{t}{\theta}\right)^{\beta}\right]$

$R(1)=2,718\left[\left(-\frac{1}{10,12718}\right)^{3,97241}\right]$

$R(1)=2,718\left[(-0,0987)^{3,97241}\right]$

$R(1)=0,9998987$

Untuk perhitungan interval (t) keandalan dari komponen impeller yang selanjutnya bisa dilihat pada tabel dibawah ini.
Tabel 6. Nilai keandalan (reliability) komponen impeller

\begin{tabular}{|c|c|}
\hline Interval $(\mathrm{t})$ & Nilai Keandalan (reliability) \\
\hline 1 & 0,9998987 \\
\hline 2 & 0,9984105 \\
\hline 3 & 0,9920678 \\
\hline 4 & 0,9753385 \\
\hline 5 & 0,9412097 \\
\hline 6 & 0,8824901 \\
\hline 7 & 0,7940496 \\
\hline 8 & 0,6757294 \\
\hline 9 & 0,5348273 \\
\hline 10 & 0,3863287 \\
\hline 11 & 0,2493744 \\
\hline 12 & 0,1405438 \\
\hline 13 & 0,0674243 \\
\hline 14 & 0,0267865 \\
\hline 15 & 0,0085552 \\
\hline 16 & 0,0021279 \\
\hline 17 & 0,0003984 \\
\hline 18 & 0,0000542 \\
\hline 19 & 0,0000051 \\
\hline 20 & 0,0000003 \\
\hline
\end{tabular}

Menentukan Interval Waktu Penggantian Komponen Impeller

Lama waktu penggantian pencegahan komponen Impeller pada mesin Hanger Shot Blast Kazo adalah kurang lebih 3 jam. Sedangkan untuk perhitungan waktu downtime perbaikan kerusakan komponen bisa dilihat pada tabel 4.4, yaitu total jam kerusakan dibagi dengan jumlah kerusakan.

$\begin{array}{ll}\text { Tp } & : 3 \text { jam } \\ \text { Tf } & : 3,55 \text { jam }\end{array}$

Perawatan Penggantian Pencegahan Metode Age Replacement Pada Komponen Impeller

Setelah menentukan waktu downtime penggantian pencegahan (Tp) dan waktu downtime perbaikan kerusakan (Tf) maka langkah selanjutnya adalah menghitung nilai minimasi downtime $\mathrm{d}(\mathrm{tp})$ interval ( $\mathrm{t})$ ke 1 dengan rumus sebagai berikut :

$$
D(t p)=\frac{T p \cdot R(t p)+T f \cdot(1-R(t p))}{(t p+T P) \cdot R(t p)+(M(t p)+T f) \cdot(1-R(t p))}
$$


Dengan nilai yang diketahui sebagai berikut :

$$
\begin{aligned}
& \text { Tp }: 3 \text { jam } \\
& \text { Tf }: 3,55 \text { jam } \\
& \mathrm{R}(1) \quad: 0,9998987 \\
& M(t p): \frac{M T T F}{1-R(t p)} \\
&: \frac{M T T F}{1-R(t p)} \\
&: \frac{9,179}{1-0,9998987} \\
&: 90576,6880 \\
& D(t p)= \frac{T p \cdot R(t p)+T f \cdot(1-R(t p))}{(t p+T P) \cdot R(t p)+(M(t p)+T f) \cdot(1-R(t p))} \\
& D(1)= \frac{3 * 0,9998987+3,55 *(0,0001013)}{(1+3) * 0,9998987+(90576,6880+3,55) *(0,0001013)} \\
& D(1)= 0,2276399
\end{aligned}
$$

Setelah nilai hasil dari d(1) diketahui maka nilai seluruh perhitungan interval (t) waktu dapat dilihat pada tabel 7 dan bisa dilihat pada gambar 5 dibawah ini.

Tabel 7. Nilai minimasi downtime komponen impeller

\begin{tabular}{|c|c|}
\hline Interval (t) & $\mathrm{D}(\mathrm{tp})$ \\
\hline 1 & 0,2276399 \\
\hline 2 & 0,2116766 \\
\hline 3 & 0,1981826 \\
\hline 4 & 0,1872486 \\
\hline 5 & 0,1792437 \\
\hline 6 & 0,1747366 \\
\hline 7 & 0,1744070 \\
\hline 8 & 0,1789290 \\
\hline 9 & 0,1887633 \\
\hline 10 & 0,2037582 \\
\hline 11 & 0,2225531 \\
\hline 12 & 0,2421988 \\
\hline 13 & 0,2589036 \\
\hline 14 & 0,2700888 \\
\hline 15 & 0,2758421 \\
\hline
\end{tabular}

\begin{tabular}{|l|l|}
\hline 16 & 0,2780806 \\
\hline 17 & 0,2787300 \\
\hline 18 & 0,2788677 \\
\hline 19 & 0,2788884 \\
\hline 20 & 0,2788906 \\
\hline
\end{tabular}

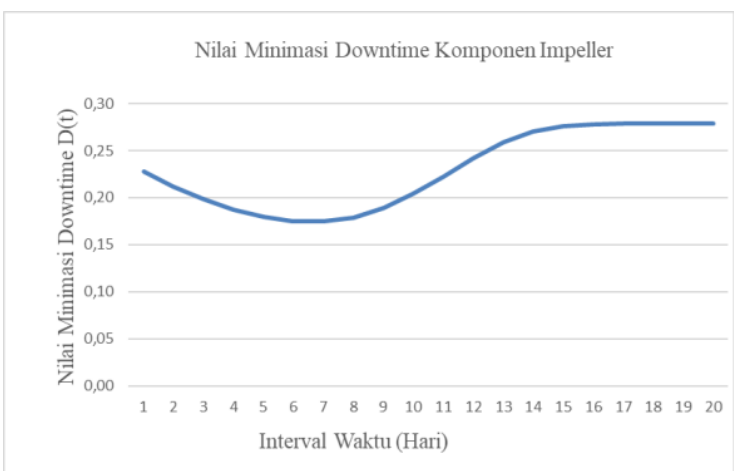

Gambar 5. Grafik nilai minimasi downtime komponen Impeller

Berdasarkan tabel dan gambar diatas, dapat diketahui nilai $\mathrm{D}(\mathrm{tp})$ yang paling kecil adalah pada interval hari ke 7 dengan nilai downtime 0,1744070. Sehingga interval waktu penggantian pencegahan komponen impeller pada mesin Hanger Shot Blast Kazo dilakukan pada hari ke 7 .

\section{Nilai Reliability Sebelum dan Sesudah Menggunakan Metode Age Replacement}

Analisis reliability dilakukan dengan cara mencari nilai MTTF lalu menghitung reliability dari komponen dengan formula yang sesuai yaitu distribusi weibull. Dari hasil perhitungan didapatkan nilai MTTF yaitu 9 hari sehingga akan dilakukan simulasi preventive maintenance pada interval 7 hari. Sehingga didapatkan nilai reliability komponen tiap waktu penggunaan dengan menggunakan waktu kelipatan 7 hari. Hasil yang didapatkan dari nilai reliability sebelum dan sesudah preventive maintenance tiap 7 hari bisa dilihat pada tabel di bawah ini.

Tabel 8. Nilai minimasi downtime komponen impeller

\begin{tabular}{|l|l|l|l|l|l|}
\hline $\mathrm{t}$ & $\mathrm{R}(\mathrm{t})$ & $\mathrm{n}$ & $\mathrm{T}$ & $\mathrm{t}-\mathrm{nT}$ & $\mathrm{R}(\mathrm{t}-\mathrm{nT})$ \\
\hline 1 & 0,9998987 & 0 & 0 & 1 & 0,9998987 \\
\hline 2 & 0,9984105 & 0 & 0 & 2 & 0,9984105 \\
\hline 3 & 0,9920678 & 0 & 0 & 3 & 0,9920678 \\
\hline 4 & 0,9753385 & 0 & 0 & 4 & 0,9753385 \\
\hline
\end{tabular}


MATRIK : Jurnal Manajemen \& Teknik Industri - Produksi Volume XXII, No.1, September 2021, Halaman 73 - 84

\begin{tabular}{|l|l|l|l|l|l|}
\hline 5 & 0,9412097 & 0 & 0 & 5 & 0,9412097 \\
\hline 6 & 0,8824901 & 0 & 0 & 6 & 0,8824901 \\
\hline 7 & 0,7940496 & 1 & 7 & 0 & 1,000000 \\
\hline 8 & 0,6757294 & 1 & 7 & 1 & 0,9998987 \\
\hline 9 & 0,5348273 & 1 & 7 & 2 & 0,9984105 \\
\hline 10 & 0,3863287 & 1 & 7 & 3 & 0,9920678 \\
\hline 11 & 0,2493744 & 1 & 7 & 4 & 0,9753385 \\
\hline 12 & 0,1405438 & 1 & 7 & 5 & 0,9412097 \\
\hline 13 & 0,0674243 & 1 & 7 & 6 & 0,8824901 \\
\hline 14 & 0,0267865 & 2 & 7 & 0 & 1,000000 \\
\hline
\end{tabular}

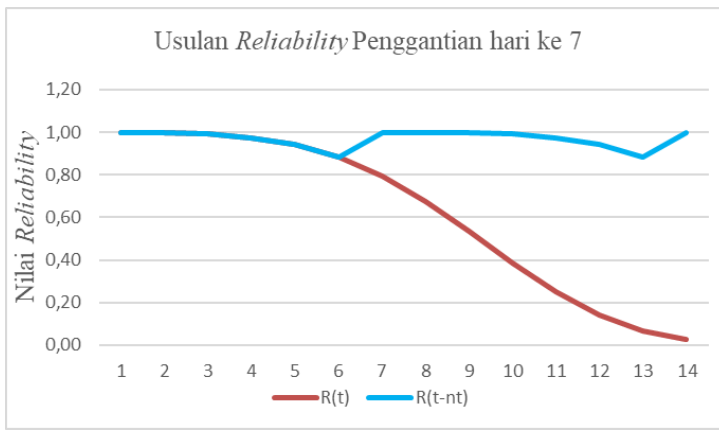

Gambar 6. Grafik nilai minimasi downtime komponen impeller

Berdasarkan gambar 6 diatas pada hari ke 1 sampai dengan hari ke 7 baik $\mathrm{R}(\mathrm{t})$ maupun $\mathrm{R}(\mathrm{nT})$ dengan keterangan $\mathrm{R}(\mathrm{t})$ garis merah adalah (sebelum menggunakan metode Age Replacement) dan $\mathrm{R}(\mathrm{nT})$ garis biru adalah (sesudah menggunakan metode Age Replacement), keduanya mengalami penurunan dikarenakan proses produksi yang terus menerus. Namun pada hari ke 7 grafik merah (sesudah melakukan penerapan metode Age Replacement) mengalami kenaikan karena telah dilakukan penggantian pencegahan komponen sehingga komponen mengalami kenaikan reliability karena kondisi masih baru.

\section{Perhitungan Biaya Kerusakan Dan Penggantian Komponen}

Biaya penggantian kerusakan (Cf) dalam 1 kali kerusakan bisa dilihat pada tabel dibawah ini.

Tabel 9. Perhitungan biaya penggantian kerusakan

\begin{tabular}{|c|c|c|}
\hline No & Keterangan & \\
\hline 1 & $\begin{array}{l}\text { Biaya tenaga kerja } \\
\text { operator }\end{array}$ & Rp 20.141/jam \\
\hline 2 & $\begin{array}{l}\text { Biaya tenaga kerja } \\
\text { maintenance ( } 3 \text { orang) }\end{array}$ & Rp 60.422 /jam \\
\hline
\end{tabular}

p-ISSN: 1693-5128, e-ISSN : 2621-8933 doi: $10.350587 /$ Matrik v22i1.2715

\begin{tabular}{|l|l|l|}
\hline 3 & $\begin{array}{l}\text { Biaya suku cadang } \\
\text { komponen } \text { impeller }\end{array}$ & $\mathrm{Rp} \mathrm{4.945.500}$ \\
\hline 4 & $\begin{array}{l}\text { Mesin keadaan berhenti } \\
\text { trip })\end{array}$ & $\mathrm{Rp} \mathrm{127.170.000/jam}$ \\
\hline 5 & $\begin{array}{l}\text { Rata-rata r waktu } \\
\text { perbaikan kerusakan } \\
\text { (Tf) }\end{array}$ & 3,55 jam \\
\hline
\end{tabular}

Untuk menghitung biaya penggantian kerusakan (Cf) adalah dengan menggunakan rumus sebagai berikut.

$C f=($ (biaya tenaga kerja + kerugian mesin dalam keadaan berhenti) x $\mathrm{Tf}$ )) + biaya suku cadang

$C f=((20.141+60.422)+127.170 .000)) \mathrm{x}$ $3,55)+4.945 .500$

$C f=((80.563+127.170 .000) \times 3,55))+$ 4.945 .500

$C f=(127.250 .563 \times 3,55)+4.945 .500$

$C f=(451.739 .499)+4.945 .500$

$C f=\operatorname{Rp} 456.684 .999 /$ kerusakan

Biaya Penggantian Pencegahan $(\mathrm{Cp})$ dalam 1 kali kerusakan bisa dilihat pada tabel dibawah ini.

Tabel 10. Perhitungan biaya penggantian pencegahan

\begin{tabular}{|l|l|l|}
\hline No & Keterangan & \\
\hline 1 & $\begin{array}{l}\text { Biaya tenaga kerja } \\
\text { maintenance (3 orang) }\end{array}$ & $\mathrm{Rp} \mathrm{60.422} \mathrm{/jam}$ \\
\hline 2 & $\begin{array}{l}\text { Biaya suku cadang } \\
\text { komponen impeller }\end{array}$ & $\mathrm{Rp} \mathrm{4.945.500}$ \\
\hline 3 & $\begin{array}{l}\text { Mesin keadaan berhenti } \\
\text { trip) }\end{array}$ & $\mathrm{Rp} \mathrm{127.170.000/jam}$ \\
\hline 4 & $\begin{array}{l}\text { Lama waktu } \\
\text { penggantian pencegahan } \\
\text { (Tp) }\end{array}$ & 3 jam \\
\hline
\end{tabular}

Untuk menghitung biaya penggantian pencegahan $(\mathrm{Cp})$ adalah dengan menggunakan rumus sebagai berikut.

$C p=($ (biaya tenaga kerja maintenance + mesin keadaan berhenti) x Tp )) + biaya suku cadang

$$
\begin{aligned}
& C p=((60.422+127.170 .000) \times 3))+ \\
& 4.945 .500 \\
& C p=(127.230 .422 \times 3)+4.945 .500 \\
& C p=381.691 .266+4.945 .500
\end{aligned}
$$


$C p=\operatorname{Rp} 386.636 .766 /$ penggantian

\section{Perhitungan Total Biaya Penggantian Kerusakan Komponen Impeller}

Biaya perawatan yang dilakukan saat penggantian kerusakan (Cf) dalam satu kali kerusakan adalah sebesar Rp 456.684.999. Jika pada periode bulan April 2019 - bulan Maret 2020 frekuensi kerusakan yang terjadi adalah sebanyak 37 kali maka total biaya yang dikeluarkan adalah sebesar Rp 456.684.999 x $37=\operatorname{Rp~16.897.344.963.~}$

\section{Perhitungan Biaya Perawatan Usulan Komponen Impeller}

Biaya perawatan jika menggunakan usulan dengan metode Age Replacement pada komponen impeller mesin Hanger Shot Blast Kazo adalah untuk 1 kali penggantian sebesar Rp 386.636.766. Jumlah waktu operasi mesin dalam bulan April 2019 - Maret 2020 (24 hari kerja/bulan x 12) adalah sebanyak 288 hari. Jika penggantian komponen menggunakan metode age replacement menggunakan rumus Jumlah Waktu Operasi Mesin Kerja

usulan interval waktu metode age replacement maka perhitungannya adalah $\frac{288 \text { hari }}{7}$ adalah 41 $(41,14)$. Untuk hasil total keseluruhan usulan biaya perawatan adalah sebesar $\mathrm{Rp} 386.636 .766$ x $41=\operatorname{Rp} 15.852 .107 .406$.

\section{Perbandingan Biaya Perawatan Dengan} Usulan Penerapan Metode Age Replacement Rekapitulasi total biaya perawatan sebelum dan sesudah menggunakan metode Age Replacement dapat dilihat pada tabel 4.17 dibawah ini.

Tabel 11. Rekapitulasi total biaya perawatan sebelum dan sesudah menggunakan metode Age Replacement

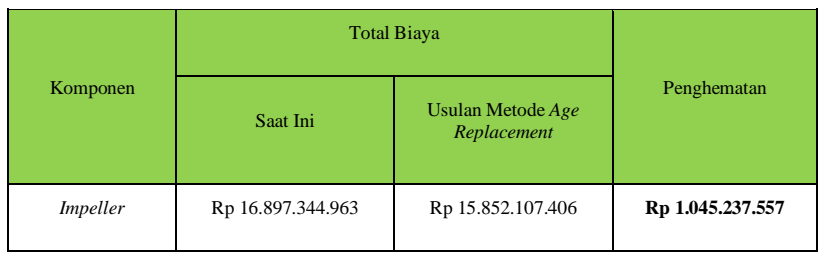

Berdasarkan hasi perhitungan dapat diketahui bahwa dengan menggunakan metode Age Replacement akan menghemat biaya perawatan pencegahan sebesar Rp Rp 16.897.344.963 $\mathrm{Rp} 15.852 .107 .406=\mathbf{R p}$ 1.045.237.557.

\section{Kesimpulan dan Saran}

Berdasarkan hasil pembahasan serta analisis yang telah dilakukan, maka diperoleh kesimpulan sebagai berikut :

1. Komponen impeller merupakan komponen yang paling kritis dikarenakan terdapat 37 kali frekuensi kerusakan pada bulan April 2019 Maret 2020 berdasarkan tabel 5.1

2. Keandalan (reliability) komponen impeller pada mesin Hanger Shot Blast Kazo adalah sebesar 53\%. Berdasarkan perhitungan nilai reliability perbandingan sebelum dan sesudah menggunakan metode Age Replacement akan meningkat sebesar 26\%, dari 53\% Menjadi 79\%.

3. Berdasarkan perhitungan interval waktu penggantian komponen kritis dengan menggunakan metode Age Replacement dengan kriteria minimasi downtime menghasilkan interval penggantian komponen kritis impeller pada interval hari ke 7.

4. Dari perhitungan total penggantian pencegahan komponen impeller pada mesin Hanger Shot Blast diketahui biaya usulan perawatannya yaitu sebesar Rp 15.852.107.406 dengan melakukan penggantian komponen selama 41 kali pada periode bulan April 2019 - Maret 2020 dan mengalami penghematan sebesar Rp 1.045.237.557.

Adapun saran yang dapat diberikan sebagai masukan bagi perusahaan dan penelitian selanjutnya adalah :

1. Perusahaan perlu menggunakan metode Age Replacement untuk mempermudah menentukan interval penggantian komponen yang optimal. Dari hasil penelitian, perusahaan harus mengganti interval waktu komponen Impeller pada hari ke 7.

2. Pencatatan mengenai data kerusakan mesin dan waktu lama perbaikan perlu dilakukan lebih teliti lagi, karena suatu jadwal perawatan akan membuat kinerja mesin meningkat.

3. Untuk penelitian selanjutnya dapat digunakan mesin, objek atau komponen yang berbeda. 


\section{Daftar Pustaka}

[1] T. Taufik and S. Septyani, "Penentuan Interval Waktu Perawatan Komponen Kritis pada Mesin Turbin Di PT Pln (Persero) Sektor Pembangkit Ombilin," J. Optimasi Sist. Ind., vol. 14, no. 2, p. 238, 2016, doi: 10.25077/josi.v14.n2.p238-258.2015.

[2] M. K. Jaka Purnama, Yosua Anggara Putra, "Metode Age Replacement Digunakan Untuk Menentukan Interval Waktu Perawatan Mesin Pada Armada Bus," Semin. Nas. Sains dan Teknol. Terap. III 2015 Inst. Teknol. Adhi Tama Surabaya ISBN, pp. 115-126, 2015.

[3] D. S. Dhamayanti, J. Alhilman, and N. Athari, "Usulan Preventive Maintenance Pada Mesin Komori Ls440 Dengan Menggunakan Metode Reliability Centered Maintenance (Rcm Ii) Dan Risk Based Maintenance (Rbm) Di Pt Abc," J. Rekayasa Sist. Ind., vol. 3, no. 02, p. 31, 2016, doi: 10.25124/jrsi.v3i02.29.

[4] M. Djunaidi and Mila Faila Sufa, "Usulan Interval Perawatan Komponen Kritis Pada Mesin Pencetak Botol ( Mould Gear ) berdasarkan Kriteria Minimasi Downtime," J. Tek. Gelagar, vol. 18, no. 1, pp. 33-41, 2007.

[5] C. Ekawati and F. H. Mustofa, "Jadwal Perawatan Preventive Pada Mesin Dyeing Menggunakan Metode Age Replacement di PT . Nobel Industries," J. Online Inst. Teknol. Nas., vol. 4, no. 2, pp. 137-148, 2016.

[6] N. A. Fikri and E. P. Widjajati, "Penentuan Interval Perawatan Mesin Air Separation Plant Secara Preventive Downtime Maintenance Dengan Menggunakan Metode Age Replacement Pada Pt. Xyz," Juminten, vol. 1, no. 3, pp. 153-164, 2020, doi: 10.33005/juminten.v1i3.114.

[7] E. Santoso and E. J. Chairul, "Minimasi Downtime Tool Punch Mesin Heading Pada Preventive Maintenance Dengan Metode Age Replacement," Ind. Syst.
Eng. Assess. J. - Discontin., vol. 8, no. 2, pp. 134-143, 2007.

[8] R. Sari, "Perancangan Sistem Pemeliharaan Menggunakan Metode Reliability Centered Maintenance (RCM) Pada Pulverizer (Studi Kasus: PLTU Paiton Unit 3)," J. Tek. ITS, vol. vol 6, no. 1, pp. 23-124, 2017, [Online]. Available: https://www.neliti.com/publications/21 4368/perancangan-sistempemeliharaan-menggunakan-metodereliability-centered-maintena.

[9] U. T. Kirana, J. Alhilman, and S. Sutrisno, "Perencanaan Kebijakan Perawatan Mesin Corazza Ff100 Pada Line 3 Pt Xyz Dengan Metode Reliability Centered Maintenance (Rcm) Ii," J. Rekayasa Sist. Ind., vol. 3, no. 01 , p. 47, 2016, doi: 10.25124/jrsi.v3i01.41.

[10] S. D. Mutiara, A. Rahman, and I. Hamdala, "PERENCANAAN PREVENTIVE MAINTENANCE KOMPONEN CANE CUTTER I DENGAN PENDEKATAN AGE REPLACEMENT ( Studi Kasus di PG Kebon Agung Malang ) PREVENTIVE MAINTENANCE IMPLEMENTATION OF CANE CUTTER I ( Case Study at PG Kebon Agung Malang ) Abstrak," pp. 396405, 2014.

[11] R. S. Prabowo, P. A. Setiawan, A. I. Juniani, Wiediartini, and I. Erawati, "Reliability analysis of hanger shot blast KAZO machine in foundry plant," MATEC Web Conf., vol. 204, pp. 1-6, 2018, doi: 10.1051/matecconf/201820403007.

[12] Y. Y. Prawiro, "Penentuan Interval Waktu Penggantian Komponen Kritis Pada Mesin Volpack Menggunakan Metode Age Replacement," J. Tek. Ind., vol. 16, no. 2, p. 92, 2017, doi: 10.22219/jtiumm.vol16.no2.92-100.

[13] A. P. Ramadhan and Iskandar, "PENENTUAN JADWAL PREVENTIVE MAINTENANCE 
MENGGUNAKAN METODE AGE REPLACEMENT PADA FORKLIFT 5 TON DI PT SWADAYA GRAHA Tujuan Penelitian Manfaat Penelitian," vol. 01, pp. 54-61, 2015.

[14] A. D. Susanto and H. H. Azwir, "Perencanaan Perawatan Pada Unit Kompresor Tipe Screw Dengan Metode RCM di Industri Otomotif," J. Ilm. Tek. Ind., vol. 17, no. 1, p. 21, 2018, doi: 10.23917/jiti.v17i1.5380.
[15] S. G. Tama and Iskandar, "PENENTUAN INTERVAL WAKTU OPTIMAL PENGGANTIAN KOMPONEN WIRE SCREEN PADA MESIN WIRE PART DENGAN METODE AGE REPLACEMENT DI PT . MOUNT DREAM INDONESIA Sega Gavin Tama Iskandar Abstrak," $J$. Tek. Mesin, vol. 5, no. 2, pp. 175-182, 2017. 